\title{
PENGEMBANGAN KUALITAS PRODUK DODOL RUMPUT LAUT UKM AULIA SARI MENGGUNAKAN INTEGRASI DIMENSI KUALITAS PRODUK DAN MODEL KANO
}

\author{
${ }^{1}$ Aziz Pratama Thahir, ${ }^{2}$ Yati Rohayati, ${ }^{3}$ Aulia F. Hadining \\ 1,2,3 Program Studi Teknik Industri, Fakultas Rekayasa Industri, Telkom University \\ 1'azizprtm@gmail.com, ${ }^{2}$ yati.rohayati.ittelkom@gmail.com, ${ }^{3}$ aulia.fasha@gmail.com
}

\begin{abstract}
Abstrak-Aulia Sari adalah satu-satunya badan usaha yang memproduksi dodol rumput laut di pulau Jawa. Jumlah penjualan dodol di Jawa Barat cukup tinggi karena merupakan salah satu oleh-oleh khas Jawa Barat. Rumput laut dodol Aulia Sari, dengan banyak manfaat yang ditawarkan dari rumput laut, tidak mendapatkan jumlah penjualan yang besar di Bandung sebagai lokasi badan usaha ini didirikan. Hal ini disebabkan oleh rendahnya tingkat kepuasan pelanggan terhadap performa produk. Penelitian ini dimaksudkan untuk meningkatkan kualitas produk rumput laut dodol agar dapat meningkatkan tingkat kepuasan pelanggan menggunakan integrasi model Kano dan dimensi kualitas produk. Keuntungan menggunakan model Kano dan dimensi kualitas produk dalam pengembangan produk telah terbukti dapat meningkatkan kinerja produk dalam beberapa penelitian sebelumnya. Penelitian ini menggunakan 4 dimensi kualitas produk yang telah disesuaikan dengan produk dalam bentuk makanan dan 22 variabel kualitas produk yang berasal dari Voice of Customer dan terintegrasi dengan model Kano. Tujuan dari penelitian ini adalah untuk mendapatkan faktorfaktor apa yang akan dipertahankan, ditingkatkan atau dihapus dari produk rumput laut dodol Aulia Sari UKM. Pada penelitian ini didapatkan 15 atribut kebutuhan yang harus diperbaiki dari produk dodol rumput laut Aulia Sari.
\end{abstract}

Kata kunci: model kano, dimensi kualitas, dodol rumput laut

\section{PENDAHULUAN}

Usaha Kecil Menengah (UKM) adalah salah satu kunci utama perekonomian di Indonesia. Jumlah UKM di Jawa Barat berjumlah 8.2 juta unit dan telah memberikan berkontribusi lebih dari $60 \%$ terhadap pendapatan perkapita di Jawa Barat [1]. Hal ini merupakan pertanda baik bagi pertumbuhan ekonomi di Jawa Barat.

Aulia Sari merupakan UKM yang bergerak di bidang olahan makanan berbahan dasar rumput laut. Salah satu produk UKM Aulia Sari yang memiliki potensi cukup tinggi adalah dodol rumput laut. Tabel I menunjukan jumlah penjualan dodol yang sangat tinggi dan cenderung meningkat setiap tahunnya. Produk dodol rumput laut Aulia Sari memiliki potensi untuk mencapai angka penjualan yang lebih tinggi jika melihat angka penjualan tahunan dodol di Jawa Barat.

Potensi lain dari produk dodol rumput laut UKM Aulia Sari adalah bahan dasar rumput laut yang memiliki banyak kelebihan diantaranya seperti kaya vitamin dan mineral (A, B12, Zat Besi, Iodium, Kalium, dll), kaya serat, dan memiliki anti-oxidant yang tinggi sehingga dapat mencegah kanker [3].

TABEL I

JUMLAH PENJUALAN DODOL DI JAWA BARAT [2]

\begin{tabular}{|c|c|c|c|c|c|}
\hline \multirow{2}{*}{ No } & \multirow{2}{*}{ Merek } & \multicolumn{4}{|c|}{ Tahun } \\
\cline { 3 - 6 } & & 2009 (ton) & 2010 (ton) & 2011 (ton) & 2012 (ton) \\
\hline 1 & Anugrah & 36.9 & 38.4 & 37.0 & 39.6 \\
\hline 2 & Pusaka & 51.3 & 54.1 & 52.8 & 54.5 \\
\hline 3 & Picnic & 63.0 & 65.0 & 66.4 & 66.0 \\
\hline 4 & Winda & 54.7 & 59.0 & 62.3 & 60.0 \\
\hline 5 & Lain-lain & 425.8 & 418.6 & 418.0 & 432.7 \\
\hline & Jumlah & 631.7 & 635.1 & 636.5 & 652.8 \\
\hline
\end{tabular}

Disamping banyaknya manfaat dari dodol ruput laut, masih ada beberapa keluhan dari konsumen mengenai dodol rumput laut Aulia Sari ini yang didapatkan dari survei pendahuluan yang dilakukan kepada 32 konsumen dodol rumput laut Aulia Sari. Beberapa keluhan dari konsumen mengenai produk dodol rumput laut UKM Aulia Sari dapat dilihat pada Tabel II.

TABEL II

KELUHAN SURVEI PENDAHULUAN

\begin{tabular}{|l|l|l|}
\hline Keluhan & Jumlah Keluhan & Persentase \\
\hline Warna kurang menarik & 16 & $50 \%$ \\
\hline Rasa kurang pas & 12 & $37.5 \%$ \\
\hline Tekstur kurang cocok & 20 & $62.5 \%$ \\
\hline Tidak terkenal & 28 & $87.5 \%$ \\
\hline
\end{tabular}

Tabel II menjelaskan bahwa selain besarnya peluang pasar, masih ada kekurangan yang dirasakan oleh konsumen pada produk dodol rumput laut UKM Aulia Sari ini yang jika tidak ditanggulangi dengan tepat akan menimbulkan kesenjangan kepuasan pelanggan [4]. Data pada Tabel II menunjukkan pengembangan produk dodol rumput laut UKM Aulia Sari sangat diperlukan dengan mengembangkan beberapa atribut dari produk 
tersebut untuk menghilangkan kesenjangan yang terjadi. Penelitian ini dilakukan dengan menggunakan integrasi model Kano dan dimensi kualitas produk yang akan menghasilkan atribut yang harus dikembangkan, dipertahankan dan dihilangkan untuk meningkatkan tingkat kepuasan pelanggan.

\section{TINJAUAN PUSTAKA}

A. Dimensi Kualitas Produk

Kualitas produk adalah karakteristik dari produk atau kemampuannya untuk memenuhi kebutuhan pelanggan yang tersurat maupun tersirat [5]. Jika UKM Aulia Sari ingin mendapatkan keunggulan bersaing di pasar, maka UKM ini harus mampu mengetahui aspek yang dapat menambah nilai dari produk maupun perusahaan di mata konsumen. Dimensi kualitas produk [6] dapat dilihat pada Tabel III.

TABEL III

DIMENSI KUALITAS PRODUK GARVIN [6]

\begin{tabular}{|l|l|}
\hline $\begin{array}{l}\text { Dimensi Kualitas } \\
\text { Produk }\end{array}$ & Definisi \\
\hline Performance & $\begin{array}{l}\text { Mengacu pada karakteristik operasi utama produk. } \\
\text { Contoh: performa mobil mencakup ciri-ciri seperti } \\
\text { akselerasi, handling, kenyamanan. }\end{array}$ \\
\hline Features & $\begin{array}{l}\text { Fitur adalah suplemen untuk fungsi dasar. Sebagai } \\
\text { contoh: gratis minuman di pesawat, tuner otomatis } \\
\text { di televisi. }\end{array}$ \\
\hline Realibility & $\begin{array}{l}\text { Mengacu pada probabilitas rusak produk atau gagal } \\
\text { dalam jangka waktu tertentu. }\end{array}$ \\
\hline Conformance & $\begin{array}{l}\text { Sejauh mana desain dan operasi karakteristik } \\
\text { produk memenuhi standar yang ditetapkan }\end{array}$ \\
\hline Durability & $\begin{array}{l}\text { Jumlah penggunaan dari produk sebelum } \\
\text { mengalami kerusakan atau harus digantikan. }\end{array}$ \\
\hline Serviceability & $\begin{array}{l}\text { Mengacu pada kecepatan, kompetensi dan } \\
\text { kemudahan perbaikan. }\end{array}$ \\
\hline Aesthetic & $\begin{array}{l}\text { Bagaimana produk terlihat, terasa, terdengar, atau } \\
\text { tercium. }\end{array}$ \\
\hline Perceived Quality & $\begin{array}{l}\text { Informasi atribut produk disajikan dalam satu } \\
\text { produk. }\end{array}$ \\
\hline
\end{tabular}

Tidak Semua dimensi kualitas pada Tabel III dapat digunakan dalam penelitian ini. Diperlukan penyesuaian dimensi kualitas terhadap objek penelitian yang merupakan produk makanan. Pemilihan dimensi kualitas yang relevan dilakukan dengan penyesuaian dengan penelitian sebelumnya dan juga expert judgment. Dimensi kualitas produk makanan dapat digunakan pada penelitian ini. Dimensi kualitas yang relevan dan penyesuaian dengan dimensi kualitas produk makanan dapat dilihat pada Tabel IV.

Dimensi kualitas produk pada Tabel IV berhubungan dengan objek penelitian karena memiliki kesamaan karakteristik produk yaitu makanan. Tujuan dari pemilihan dimensi kualitas ini adalah untuk memperkuat analisis mengenai dimensi yang akan digunakan selanjutnya. Dari dimensi kualitas produk ini, akan didapatkan dimensi kualitas produk yang lemah dan yang kuat yang nantinya akan digunakan dalam pengambilan keputusan pengembangan produk.
TABEL IV

DIMENSI KUALITAS PRODUK RELEVAN

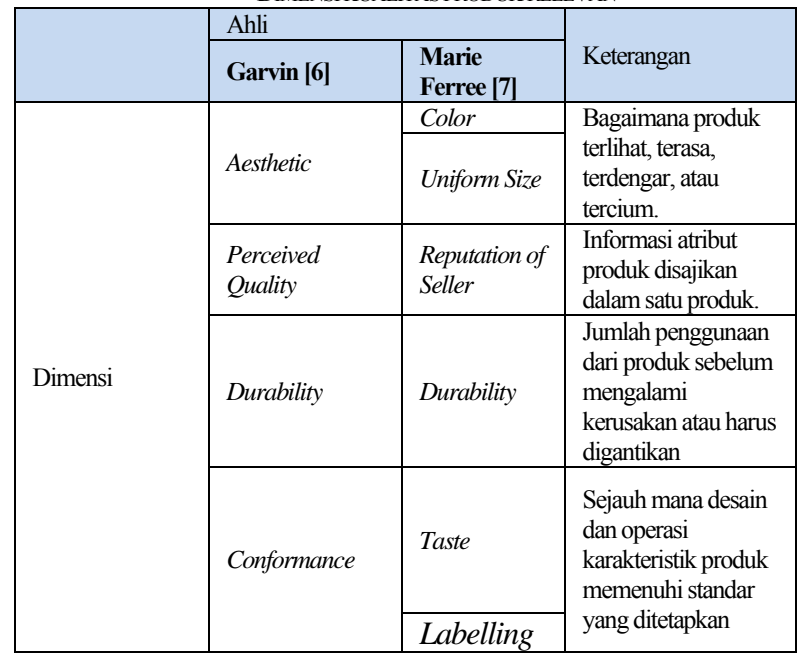

B. Model Kano

Model Kano membedakan enam jenis persyaratan produk yang memengaruhi kepuasan pelanggan dengan cara yang berbeda saat ditemui [8]:

1. Kategori Must-be

Pelanggan menganggap bahwa atribut yang ada dalam kategori ini merupakan suatu keharusan yang ada dalam produk. Pelanggan akan merasa tidak puas ketika performansi atribut produk (barang atau jasa) rendah, namun kepuasan pelanggan tidak akan meningkat melebihi area netral meskipun performansi atribut produk tinggi.

2. Kategori One-Dimensional

Kepuasan pelanggan akan meningkat jika atribut yang ada dalam kategori ini diberikan, namun pelanggan tidak akan puas jika atribut yang ada dalam kategori ini tidak ada. Dapat dikatakan bahwa ketersediaan atribut dalam kategori ini berbanding lurus atau linear dengan peningkatan kepuasan pelanggan.

3. Kategori Attractive

Pelanggan akan merasa puas jika atribut yang ada dalam kategori ini diberikan, namun pelanggan tidak akan kecewa jika atribut dalam kategori ini tidak diberikan. Tingkat kepuasan pelanggan akan meningkat sangat tinggi dengan meningkatnya kinerja atribut, akan tetapi penurunan kinerja atribut tidak akan menyebabkan penurunan tingkat kepuasan. Pemberian atribut dalam kategori ini akan memberikan kesenangan yang mengejutkan bagi pelanggan serta dapat memberikan perbedaan dari produk pesaing bahkan mengungguli pesaing. Atribut dalam kategori ini memiliki nilai diferensiasi positif dan menjadikan perusahaan lebih kompetitif dalam persaingan pasar. Biasanya pelanggan mau membayar lebih untuk pemberian atribut yang ada dalam kategori ini.

4. Kategori Indifferent

Kategori ini dilihat sebagai kebutuhan yang netral bagi pelanggan dan tidak berpengaruh kepada kepuasan dan 
ketidakpuasan pelanggan jika disediakan. Hal ini berarti bahwa pelanggan tidak memperhatikan kebutuhan ini.

\section{Kategori Reverse}

Pada kategori ini, kepuasan pelanggan akan menurun dengan adanya pemenuhan atribut terhadap suatu kebutuhan. Sebaliknya, pelanggan akan merasa puas jika atribut tersebut dihilangkan atau tidak disediakan.

6. Kategori Questionable

Situasi ini terjadi ketika ada kontradiksi pada jawaban pelanggan terhadap suatu pertanyaan yang berpasangan. Questionable mengindikasikan bahwa adanya ketidaksesuaian pertanyaan, kesalahpahaman terhadap pertanyaan, atau respon yang tidak tepat. Kebutuhan pelanggan tidak dapat diterjemahkan secara jelas dalam dimensi ini.

Penentuan kategori untuk setiap atribut berdasarkan Model Kano didapatkan dengan mengklasifikasikan kategori antara jawaban pada pernyataan functional dan pernyataan dysfunctional pada kuesioner Model Kano [8]. Keuntungan yang diperoleh dalam pengklasifikasian kebutuhan pelanggan dengan menggunakan Model Kano adalah [8].

1. Dapat mengidentifikasi atribut kebutuhan dari produk atau jasa yang memiliki pengaruh besar terhadap kepuasan pelanggan.

2. Prioritas pengembangan produk. Sebagai contoh, tidak terlalu berguna mengalokasikan sumberdaya yang besar dan berlebihan untuk klasifikasi produk atau atribut berkategori must be, lebih baik mengalokasikan sumberdaya tersebut untuk produk atau atribut berkategori one dimensional dan attractive.

3. Model Kano menyediakan panduan berharga dalam situasi trade-off. Bila terdapat dua atribut produk atau jasa yang tidak dapat dilaksanakan bersamaan sehubungan dengan alasan teknis atau keuangan, maka atribut yang dipilih adalah yang memiliki pengaruh besar terhadap kepuasan pelanggan.

4. Penggunaan Model Kano dapat menciptakan perbedaan atau diferensiasi produk atau jasa dengan cara menganalisa atribut yang menarik (attractive attribute). Atribut inilah yang menjadi kunci dalam memenangkan persaingan pasar.

Model kano dalam penelitian ini akan menghasilkan kategori kano dan menjadi masukan untuk pertimbangan pengembangan produk.

\section{Integrasi Dimensi Kualitas Produk dan Model Kano}

Penelitian ini dibuat menggunakan pengintegrasian dimensi kualitas produk dan Model Kano karena tidak semua atribut kebutuhan yang didapatkan dari pelanggan merupakan atribut yang perlu dipertahankan atau dikembangkan. Atribut yang didapatkan akan dikelompokkan berdasarkan dimensi kualitas produk dan pengategorian atribut berdasarkan kepuasan pelanggan menggunakan Model Kano. Sistemasi pengintegrasian dilakukan dengan panduan penelitian sebelumnya, yaitu penelitian peningkatan kualitas sebuah pelayanan menggunakan integrasi model Kano dan SERVQUAL [9].

Pengukuran kualitas produk menggunakan kuesioner dimensi kualitas produk akan menghasilkan pengategorian atribut kebutuhan yaitu kuat dan lemah, sementara itu kuesioner Model Kano akan menghasilkan pengategorian atribut kebutuhan yaitu kategori Must-be, One-Dimensional, Indifferent, Attractive, Reverse dan Questionable. Atribut atribut yang diperoleh dari kedua pengukuran tersebut akan diintegrasikan sehingga akan diketahui atribut kebutuhan mana yang perlu dikembangkan, dipertahankan atau dihilangkan.

Atribut kebutuhan dengan kategori kuat dari kuesioner dimensi kualitas produk dan memiliki kategori Kano Attractive serta atribut kebutuhan denan kategori lemah dan memiliki kategori Kano Must Be, One Dimensional, dan Attractive akan menjadi atribut kebutuhan yang perlu dikembangkan. Atribut kuat dengan kategori Kano Must Be akan dipertahankan. Atribut kuat atau lemah dengan kategori Kano Indifferent, Questionable, Reverse perlu dihilangkan.

\section{METODOLOGI PENELITIAN}

Penelitian ini berisi studi untuk mendapatkan atribut yang akan ditingkatkan, dipertahankan, dan dihapus untuk pengembangan kualitas produk dodol rumput laut Aulia Sari. Penelitian ini akan dilakukan sesuai dengan model konseptual pada Gambar 2.

Gambar 2 menjelaskan bahwa atribut kebutuhan pada studi ini dikelompokan berdasarkan dimensi kualitas produk yaitu: Aesthetic, Perceived Quality, Conformance, dan Reliability. Atribut kualitas ini akan menjadi landasan untuk mencari data kepuasan konsumen terhadap performa atribut suatu produk dan kategori kano dari atribut produk. Kemudian model Kano dan dimensi kualitas produk akan diintegrasikan untuk mengetahui atribut mana saja dari produk tersebut yang akan ditingkatkan, dipertahankan dan dihilangkan. Atribut yang harus ditingkatkan menjadi true customer needs dari produk tersebut.

Ada 2 jenis kuesioner yang digunakan dalam studi ini, yaitu: kuesioner dimensi kualitas produk dan kuesioner model Kano.

Kuesioner dimensi kualitas produk digunakan untuk mendapatkan hasil berupa tingkat kepuasan, kepentingan dan harapan konsumen terhadap performa produk yang akan menjadi masukan untuk pengelompokan atribut kebutuhan kedalam kelompok atribut lemah atau kuat. Atribut dengan nilai kepuasan pelanggan (NKP) positif menjadi atribut kuat, dan yang memiliki NKP negatif menjadi atribut lemah.

Kuesioner model Kano dinyatakan dalam bentuk dysfunctional dan functional. Hasil dari kuesioner ini adalah atribut kebutuhan yang dikelompokan kedalam kategori Kano. Hasil dari integrasi model Kano dan dimensi kualitas produk akan menghasilkan true customer needs yaitu atribut lemah dengan kategori Kano: Must be, One-Dimensional, dan Attractive serta atribut kuat dengan kategori kano: Attractive. 


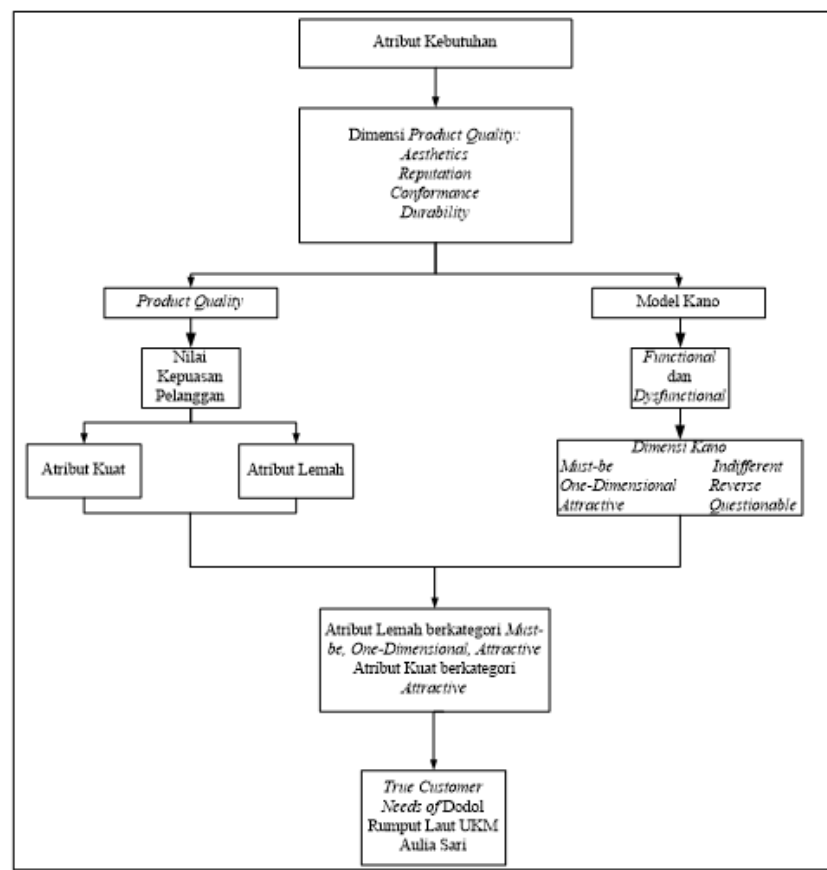

Gambar 2. Model konseptual

\section{HASIL DAN PEMBAHASAN}

\section{A. Voice of Customer}

Penelitian pendahuluan dilakukan untuk mendapatkan apa saja keluhan yang dirasakan oleh konsumen terkait dengan dimensi kualitas produk makanan. Penelitian pendahuluan dilakukan dengan wawancara menggunakan pertanyaan terbuka kepada 32 konsumen dodol rumput laut Aulia Sari. $V o C$ dari penelitian pendahuluan dapat dilihat pada Tabel V.

Variabel pada Tabel $\mathrm{V}$ akan dirancang menjadi kuesioner dimensi kualitas produk dan juga model kano. Sampling yang digunakan dalam penelitian ini adalah purposive sampling yaitu teknik sampling dengan sample pilihan untuk memperlancar tujuan penelitian [10].

\section{B. Pengkodean Atribut Kebutuhan}

Pengkodean atribut kebutuhan dilakukan untuk memudahkan tahap rekapitulasi pengolahan data masingmasing atribut dari kuesioner kualitas produk dan model Kano. Setiap atribut diberi kode huruf berdasarkan dimensi kualitas produk dan diikuti dengan nomor urut. Pengkodean atribut kebutuhan dapat dilihat pada Lampiran A.

\section{Kuesioner Kualitas Produk}

Pengolahan kuesioner kualitas produk dilakukan untuk menghitung kesenjangan atau selisih antara nilai kepuasan dan nilai harapan dari produk rumput laut dodol. Nilai kesenjangan kemudian akan dikalikan dengan nilai kepentingan yang diperoleh dari kuesioner kualitas produk menjadi nilai kepuasan pelanggan. Perhitungan nilai kesenjangan dan NKP dapat dilihat pada Tabel VI.
TABEL V

VOICE OFCUSTOMER

\begin{tabular}{|c|c|}
\hline Dimensi & Voice of Customer \\
\hline \multirow{7}{*}{ Aesthetic } & $\begin{array}{l}\text { Keseimbangan perpaduan Gambar } \\
\text { dan tulisan kemasan }\end{array}$ \\
\hline & $\begin{array}{l}\text { Harmonisasi perpaduan warna } \\
\text { kemasan }\end{array}$ \\
\hline & Terdapat logo pada kemasan \\
\hline & Kejelasan penulisan pada kemasan \\
\hline & Aroma dodol mencerminkan rasa \\
\hline & Harmonisasi warna dan rasa dodol \\
\hline & Kesamaan ukuran dodol \\
\hline Reputation & $\begin{array}{l}\text { Keidentikan Brand Aulia Sari dengan } \\
\text { olahan rumput laut }\end{array}$ \\
\hline \multirow{3}{*}{ Reputation } & $\begin{array}{l}\text { Iklan Aulia Sari Tersebar diberbagai } \\
\text { media promosi }\end{array}$ \\
\hline & $\begin{array}{l}\text { Tercantum informasi mengenai } \\
\text { outlet pada kemasan }\end{array}$ \\
\hline & $\begin{array}{l}\text { Ketersediaan dodol rumput laut } \\
\text { di outlet }\end{array}$ \\
\hline \multirow{9}{*}{ Conformance } & $\begin{array}{l}\text { Terdapat label halal pada } \\
\text { kemasan }\end{array}$ \\
\hline & $\begin{array}{l}\text { Tercantum berat produk pada } \\
\text { kemasan }\end{array}$ \\
\hline & $\begin{array}{l}\text { Kejelasan penulisan tanggal } \\
\text { kadaluarsa produk pada kemasan }\end{array}$ \\
\hline & $\begin{array}{l}\text { Terdapat komposisi bahan baku } \\
\text { yang digunakan pada kemasan }\end{array}$ \\
\hline & $\begin{array}{l}\text { Terdapat informasi nilai gizi pada } \\
\text { kemasan }\end{array}$ \\
\hline & $\begin{array}{l}\text { Kecocokan pengaplikasian rasa } \\
\text { buah pada dodol }\end{array}$ \\
\hline & $\begin{array}{l}\text { Terdapat label dan nomor lolos } \\
\text { uji dari Departemen Kesehatan } \\
\text { pada kemasan }\end{array}$ \\
\hline & Kekenyalan dodol \\
\hline & Kerenyahan dodol \\
\hline \multirow{2}{*}{ Durability } & Ketahanan kemasan \\
\hline & Ketahanan produk (waktu) \\
\hline
\end{tabular}

TABEL VI

HASIL KUESIONER DIMENSI KUALTTAS PRODUK

\begin{tabular}{|c|c|c|c|c|c|c|}
\hline No & $\begin{array}{c}\text { Kode } \\
\text { Atribut }\end{array}$ & Harapan & Kepuasan & Selisih & Kepentingan & NKP \\
\hline 1 & AES_1 & 3,21 & 3,13 & $-0,08$ & 3,13 & $-0,25$ \\
\hline 2 & AES_2 & 3,12 & 3,20 & 0,08 & 3,20 & 0,26 \\
\hline 3 & AES_3 & 3,20 & 3,22 & 0,02 & 3,13 & 0,06 \\
\hline 4 & AES_4 & 3,20 & 3,19 & $-0,01$ & 3,20 & $-0,03$ \\
\hline 5 & AES_5 & 3,19 & 3,22 & 0,03 & 3,20 & 0,10 \\
\hline 6 & AES_6 & 3,20 & 3,13 & $-0,07$ & 3,19 & $-0,22$ \\
\hline 7 & AES_7 & 3,20 & 3,18 & $-0,02$ & 3,20 & $-0,06$ \\
\hline 8 & REP_1 & 3,21 & 3,20 & $-0,01$ & 3,19 & $-0,03$ \\
\hline 9 & REP_2 & 3,14 & 3,13 & $-0,01$ & 3,20 & $-0,03$ \\
\hline 10 & REP_3 & 3,21 & 3,13 & $-0,08$ & 3,20 & $-0,26$ \\
\hline 11 & REP 4 & 3,20 & 3,18 & $-0,02$ & 3,13 & $-0,06$ \\
\hline 12 & CON_1 & 3,17 & 3,19 & 0,02 & 3,19 & 0,06 \\
\hline 13 & CON_2 & 3,12 & 3,21 & 0,09 & 3,13 & 0,28 \\
\hline 14 & CON_3 & 3,18 & 3,20 & 0,02 & 3,20 & 0,06 \\
\hline 15 & CON_4 & 3,19 & 3,14 & $-0,05$ & 3,20 & $-0,16$ \\
\hline 16 & CON_5 & 3,18 & 3,20 & 0,02 & 3,19 & 0,06 \\
\hline 17 & CON_6 & 3,11 & 3,12 & 0,01 & 3,13 & 0,03 \\
\hline 18 & CON_7 & 3,19 & 3,20 & 0,01 & 3,20 & 0,03 \\
\hline 19 & CON_8 & 3,20 & 3,17 & $-0,03$ & 3,20 & $-0,10$ \\
\hline 20 & CON_9 & 3,20 & 3,18 & $-0,02$ & 3,20 & $-0,06$ \\
\hline 21 & DUR_1 & 3,20 & 3,40 & 0,20 & 3,40 & 0,68 \\
\hline 22 & DUR_2 & 3,45 & 3,21 & $-0,24$ & 3,44 & $-0,83$ \\
\hline
\end{tabular}


Atribut kebutuhan yang memiliki NKP positif berarti bahwa atribut dikategorikan sebagai atribut yang kuat, sementara kebutuhan atribut yang memiliki negatif NKP berarti bahwa atribut tersebut dikategorikan sebagai atribut lemah.

\section{Kuesioner Model Kano}

Pengolahan kuesioner model kano dilakukan dengan mengelompokkan setiap kebutuhan atribut menggunakan Kano kategori, yaitu Must Be (M), One Dimension (O), Attractive (A), Indifferent (I), Reverse (R), dan Questionable (Q). Kategorisasi ini dinilai dengan melihat jawaban responden dari setiap kebutuhan atribut dengan pernyataan functional dan disfunctional dari kuesioner model Kano. Untuk menentukan kategori Kano dari setiap atribut dapat dilakukan dengan menggunakan rumus Blauth[11]. Hasil dari pengolahan kuesioner model Kano dapat dilihat pada Tabel VII.

TABEL VII

HASIL PENGOLAHAN KUESIONER MODEL KANO

\begin{tabular}{|c|c|c|c|c|c|c|c|c|c|}
\hline $\begin{array}{c}\text { Kode } \\
\text { atribut }\end{array}$ & $\mathrm{A}$ & $\mathrm{O}$ & $\mathrm{M}$ & $\begin{array}{c}\mathrm{O}+\mathrm{A} \\
+\mathrm{M}\end{array}$ & $\mathrm{Q}$ & $\mathrm{R}$ & $\mathrm{I}$ & $\begin{array}{c}\mathrm{Q}+\mathrm{R} \\
+\mathrm{I}\end{array}$ & $\begin{array}{c}\text { Kategori } \\
\text { Kano }\end{array}$ \\
\hline AES_1 & 25 & 23 & $\mathbf{2 9}$ & $\mathbf{7 7}$ & 0 & 0 & 43 & 43 & $\mathrm{O}$ \\
\hline AES_2 & 24 & 10 & $\mathbf{2 7}$ & $\mathbf{6 1}$ & 0 & 0 & 59 & 59 & $\mathrm{M}$ \\
\hline AES_3 & 28 & 4 & $\mathbf{2 9}$ & $\mathbf{6 1}$ & 0 & 0 & 59 & 59 & $\mathrm{M}$ \\
\hline AES_4 & 22 & 15 & $\mathbf{2 7}$ & $\mathbf{6 4}$ & 0 & 0 & 56 & 56 & $\mathrm{M}$ \\
\hline AES_5 & $\mathbf{3 4}$ & 13 & 21 & $\mathbf{6 8}$ & 0 & 0 & 52 & 52 & $\mathrm{~A}$ \\
\hline AES_6 & $\mathbf{5 0}$ & 11 & 15 & $\mathbf{7 6}$ & 0 & 0 & 44 & 44 & $\mathrm{~A}$ \\
\hline AES_7 & 23 & 10 & $\mathbf{2 8}$ & $\mathbf{6 1}$ & 0 & 0 & 59 & 59 & $\mathrm{M}$ \\
\hline REP_1 & $\mathbf{5 1}$ & 17 & 15 & $\mathbf{8 3}$ & 0 & 0 & 37 & 37 & $\mathrm{~A}$ \\
\hline REP_2 & 27 & 22 & $\mathbf{3 3}$ & $\mathbf{8 2}$ & 0 & 0 & 38 & 38 & $\mathrm{M}$ \\
\hline REP_3 & 18 & 18 & $\mathbf{4 5}$ & $\mathbf{8 1}$ & 0 & 0 & 39 & 39 & $\mathrm{M}$ \\
\hline REP 4 & 20 & 23 & $\mathbf{3 5}$ & $\mathbf{7 8}$ & 0 & 0 & 42 & 42 & $\mathrm{M}$ \\
\hline CON_1 & 23 & 17 & $\mathbf{3 5}$ & $\mathbf{7 5}$ & 0 & 0 & 45 & 45 & $\mathrm{M}$ \\
\hline CON_2 & 27 & 13 & $\mathbf{2 8}$ & $\mathbf{6 8}$ & 0 & 0 & 52 & 52 & $\mathrm{M}$ \\
\hline CON_3 & 28 & 11 & $\mathbf{2 9}$ & $\mathbf{6 8}$ & 0 & 0 & 52 & 52 & $\mathrm{M}$ \\
\hline CON_4 & 27 & 17 & $\mathbf{3 0}$ & $\mathbf{7 4}$ & 0 & 0 & 46 & 46 & $\mathrm{M}$ \\
\hline CON_5 & 21 & 23 & $\mathbf{2 9}$ & $\mathbf{7 3}$ & 0 & 0 & 47 & 47 & $\mathrm{M}$ \\
\hline CON_6 & $\mathbf{7 2}$ & 23 & 8 & $\mathbf{1 0 3}$ & 0 & 0 & 17 & 17 & $\mathrm{~A}$ \\
\hline CON_7 & 29 & 10 & $\mathbf{3 0}$ & $\mathbf{6 9}$ & 0 & 0 & 51 & 51 & $\mathrm{M}$ \\
\hline CON_8 & 17 & 20 & $\mathbf{2 8}$ & $\mathbf{6 5}$ & 0 & 0 & 55 & 55 & $\mathrm{M}$ \\
\hline CON_9 & $\mathbf{3 6}$ & 9 & 30 & $\mathbf{7 5}$ & 0 & 0 & 45 & 45 & $\mathrm{~A}$ \\
\hline DUR_1 & 1 & $\mathbf{5 2}$ & 12 & $\mathbf{6 5}$ & 0 & 0 & 55 & 55 & $\mathrm{M}$ \\
\hline DUR_2 & 2 & $\mathbf{4 8}$ & 16 & $\mathbf{6 6}$ & 0 & 0 & 54 & 54 & $\mathrm{M}$ \\
\hline
\end{tabular}

Hasil pengolahan kano pada Tabel VII menunjukan ada 1 atribut dengan kategori kano One Dimensional, 5 atribut dengan kategori kano Attractive, dan 16 atribut dengan kategori Kano Must $\mathrm{Be}$.

\section{E. Integrasi Model Kano dan Dimensi Kualitas Produk}

Setelah mendapatkan hasil berupa atribut kuat dan lemah dari pengolahan kuesioner dimensi kualitas produk, dan atribut dengan kategori kano dari hasil pengolahan keusioner model Kano, maka hasil yang diperoleh tersebut dapat diintegrasikan dengan tujuan untuk mendapatkan atribut kebutuhan apa saja yang akan ditingkatkan, dipertahankan, dan dihilangkan. Hasil dari integrasi kualitas produk dan model Kano dapat dilihat pada Tabel VII.

Atribut yang harus ditingkatkan adalah atribut lemah berdasarkan kuesioner dimensi kualias produk dengan kategori Kano Attractive, Must Be, dan One Dimensional dari hasil kuesioner model Kano dan atribut kuat dengan kategori Kano Attractive. Atribut yang harus dipertahankan adalah atribut kuat dengan katergori kano Must Be.

TABEL VIII

HASIL INTEGRASI DIMENSI KUALITAS PRODUK DAN MODEL KANO

\begin{tabular}{|c|c|c|c|c|}
\hline $\begin{array}{c}\text { Kode } \\
\text { Atribut }\end{array}$ & NKP & $\begin{array}{c}\text { Kuat / } \\
\text { Lemah }\end{array}$ & $\begin{array}{c}\text { Kategori } \\
\text { Kano }\end{array}$ & Prioritas \\
\hline AES_1 & -0.25 & Lemah & O & Ditingkatkan \\
\hline AES_2 & 0.26 & Kuat & M & Dipertahankan \\
\hline AES_3 & 0.06 & Kuat & M & Dipertahankan \\
\hline AES_4 & -0.03 & Lemah & M & Ditingkatkan \\
\hline AES_5 & 0.10 & Kuat & A & Ditingkatkan \\
\hline AES_6 & -0.22 & Lemah & A & Ditingkatkan \\
\hline AES_7 & -0.06 & Lemah & M & Ditingkatkan \\
\hline REP_1 & -0.03 & Lemah & A & Ditingkatkan \\
\hline REP_2 & -0.03 & Lemah & M & Ditingkatkan \\
\hline REP_3 & -0.26 & Lemah & M & Ditingkatkan \\
\hline REP_4 & -0.06 & Lemah & M & Ditingkatkan \\
\hline CON_1 & 0.06 & Kuat & M & Dipertahankan \\
\hline CON_2 & 0.28 & Kuat & M & Dipertahankan \\
\hline CON_3 & 0.06 & Kuat & M & Dipertahankan \\
\hline CON_4 & -0.16 & Lemah & M & Ditingkatkan \\
\hline CON_5 & 0.06 & Kuat & M & Dipertahankan \\
\hline CON_6 & 0.03 & Kuat & A & Ditingkatkan \\
\hline CON_7 & 0.03 & Kuat & M & Dipertahankan \\
\hline CON_8 & -0.10 & Lemah & M & Ditingkatkan \\
\hline CON_9 & -0.06 & Lemah & A & Ditingkatkan \\
\hline DUR_1 & 0.68 & Kuat & M & Dipertahankan \\
\hline DUR_2 & -0.83 & Lemah & M & Ditingkatkan \\
\hline
\end{tabular}

Hasil penelitian ini adalah 14 atribut yang harus ditingkatkan dan 8 atribut yang harus dipertahankan. Tidak ada atribut yang harus dihilangkan pada penelitian ini.

\section{F. True Customer Needs}

True customer needs adalah atribut kebutuhan yang paling diharapkan oleh konsumen. Atribut atribut ini perlu diberikan perhatian yang lebih besar oleh produsen. Atribut yang dikategorikan sebagai true customer needs adalah atribut lemah dengan kategori Kano Must Be, One Dimensional, Attractive dan atribut kuat dengan kategori Kano Attractive. Atribut ini perlu dianalisis dan ditingkatkan oleh pihak produsen. True customer needs dari produk dodol rumput laut Aulia Sari dapat dilihat pada Tabel IX.

TABEL IX

\begin{tabular}{|c|c|l|}
\multicolumn{4}{|c|}{ TRUE CUSTOMER NEEDSDARI DODOL RUMPUT LAUT AULIA SARI } \\
\hline No & $\begin{array}{c}\text { Kode } \\
\text { Atribut }\end{array}$ & \multicolumn{1}{c|}{ Atribut Kebutuhan } \\
\hline 1 & AES_1 & $\begin{array}{l}\text { Keseimbangan perpaduan Gambar dan tulisan } \\
\text { pada kemasan }\end{array}$ \\
\hline 2 & AES_4 & Kejelasan penulisan pada kemasan \\
\hline 3 & AES_5 & Aroma dodol rumput laut mencerminkan rasa \\
\hline 4 & AES_6 & Harmonisasi warna dan rasa dodol \\
\hline 5 & AES_7 & Kesamaan ukuran dodol \\
\hline 6 & REP_1 & $\begin{array}{l}\text { Brand Aulia Sari identik dengan olahan rumput } \\
\text { laut }\end{array}$ \\
\hline 7 & REP_2 & $\begin{array}{l}\text { Iklan Aulia Sari tersebar di berbagai media } \\
\text { promosi }\end{array}$ \\
\hline 8 & REP_3 & $\begin{array}{l}\text { Mencantumkan informasi mengenai outlet } \\
\text { alamat dan nomor telepon) pada kemasan }\end{array}$ \\
\hline 9 & REP_4 & Ketersediaan dodol rumput laut di outlet \\
\hline 10 & CON_4 & $\begin{array}{l}\text { Terdapat komposisi bahan baku yang } \\
\text { digunakan pada kemasan }\end{array}$ \\
\hline 11 & CON_6 & $\begin{array}{l}\text { Kecocokan pengaplikasian rasa buah pada } \\
\text { dodol }\end{array}$ \\
\hline
\end{tabular}




\begin{tabular}{|c|c|l|}
\hline No & $\begin{array}{c}\text { Kode } \\
\text { Atribut }\end{array}$ & \multicolumn{1}{c|}{ Atribut Kebutuhan } \\
\hline 12 & CON_8 & Kekenyalan dodol \\
\hline 13 & CON_9 & Kerenyahan dodol \\
\hline 14 & DUR_2 & Ketahanan dodol (waktu) \\
\hline
\end{tabular}

\section{KESIMPULAN}

Penelitian terhadap dodol rumput laut Aulia Sari mendapatkan hasil yang bisa disimpulkan yaitu: terdapat 22 atribut kebutuhan yang didapatkan dari Voice of Customer dan berkaitan dengan dimensi kualitas produk makanan yaitu Aesthetic, Reputation, Conformance, dan Durability. Berdasarkan pengolahan data kuesioner dimensi kualitas produk, didapatkan 10 atribut kuat yang sudah cukup memenuhi kepuasan pelanggan dan 12 atribut lemah yang belum memenuhi tingkat kepuasan pelanggan. Berdasarkan integrasi model Kano dan dimensi kualitas produk, terdapat 14 atribut dodol rumput laut Aulia Sari yang harus ditingkatkan.

Sesuai dengan kesanggupan UKM Aulia Sari untuk melakukan perbaikan performa atribut dodol rumput laut, yang sangat penting untuk dilakukan saat ini adalah perbaikan masa kedaluwarsa dari produk dodol rumput laut dengan memperbaiki resep yang digunakan.

\section{DAFTAR PUSTAKA}

[1] http://swa.co.id/business-strategy/marketing/kadintargetkan-pertumbuhan-ukm-2-di-jabar, diakses Oktober 2014.

[2] http://diperindag.jabarprov.go.id, diakses Desember 2014

[3] http://biotropika.ub.ac.id/index.php/biotropika/article/v iew/186, Diakses November 2014.

[4] http://Thesis.binus.ac.id, Diakses Februari 2015.

[5] Kotler, Phillip., Marketing Management Millenium Edition, Edisi 10, Prentice-Hall, 2000.

[6] Garvin, David A., Competing on the eight Dimensions of Quality, Harvard Business Review, No. 87603, 1987, pp. 102 $-109$.

[7] Ferree, Marie., What is Food Quality?, Journal of Food Distributuion Research, 1973, pp. 34 - 36.

[8] Kano. N., Seraku, K., Takahashi, Attractive Quality and Must Be Quality, Journal of Japanese Society for Quality Control. Volume 14, Number 2, 1984, pp. 39 - 48.

[9] Tan, Kay., Pawitra, Theresia., Integrating SERVQUAL and Kano's Model into QFD for service excellence development, Managing Service Quality: An International Journal, Volume 11, 2001, pp. 418 - 430.

[10] Sugiyono., Metode penelitian kuantitatif kualitatif dan R\&D, Edisi 17, Alfabeta, 2012

[11] [11] Kano N, and Seraku K. Attractive Quality and Must Be Quality. Journal of Japanese Society for Quality Control, Volume 14, 1984, pp. $39-48$.
LAMPIRAN

Lampiran A: Pengkodean Atribut Kebutuhan

\begin{tabular}{|c|c|c|c|}
\hline No. & $\begin{array}{c}\text { Dimensi Kualitas } \\
\text { Produk }\end{array}$ & Atribut Kebutuhan & $\begin{array}{c}\text { Kode } \\
\text { Atribut }\end{array}$ \\
\hline \multirow{7}{*}{1} & \multirow{7}{*}{ Aesthetics } & $\begin{array}{c}\text { Keseimbangan } \\
\text { perpaduan Gambar dan } \\
\text { tulisan pada kemasan }\end{array}$ & AES1 \\
\hline & & $\begin{array}{c}\text { Harmonisasi perpaduan } \\
\text { warna pada kemasan }\end{array}$ & AES2 \\
\hline & & $\begin{array}{l}\text { Terdapat logo Aulia } \\
\text { Sari pada kemasan }\end{array}$ & AES3 \\
\hline & & $\begin{array}{c}\text { Kejelasan penulisan } \\
\text { pada kemasan }\end{array}$ & AES4 \\
\hline & & $\begin{array}{l}\text { Aroma dodol rumput } \\
\text { laut mencerminkan rasa }\end{array}$ & AES5 \\
\hline & & $\begin{array}{l}\text { Harmonisasi warna dan } \\
\text { rasa dodol }\end{array}$ & AES6 \\
\hline & & $\begin{array}{c}\text { Kesamaan ukuran } \\
\text { dodol }\end{array}$ & AES7 \\
\hline \multirow{4}{*}{2} & \multirow{4}{*}{ Reputation } & $\begin{array}{c}\text { Brand Aulia Sari } \\
\text { identik dengan olahan } \\
\text { rumput laut }\end{array}$ & $R E P 1$ \\
\hline & & $\begin{array}{l}\text { Iklan Aulia Sari } \\
\text { tersebar di berbagai } \\
\text { media promosi }\end{array}$ & $R E P 2$ \\
\hline & & $\begin{array}{c}\text { Mencantumkan } \\
\text { informasi mengenai } \\
\text { outlet (alamat dan } \\
\text { nomor telepon) pada } \\
\text { kemasan }\end{array}$ & REP3 \\
\hline & & $\begin{array}{l}\text { Ketersediaan dodol } \\
\text { rumput laut di outlet }\end{array}$ & REP4 \\
\hline \multirow{9}{*}{3} & \multirow{9}{*}{ Conformance } & $\begin{array}{c}\text { Terdapat label halal } \\
\text { pada kemasan }\end{array}$ & CON1 \\
\hline & & $\begin{array}{l}\text { Mencantumkan berat } \\
\text { produk pada kemasan }\end{array}$ & CON2 \\
\hline & & $\begin{array}{l}\text { Kejelasan penulisan } \\
\text { tanggal kadaluarsa } \\
\text { produk pada kemasan }\end{array}$ & CON3 \\
\hline & & $\begin{array}{c}\text { Terdapat komposisi } \\
\text { bahan baku yang } \\
\text { digunakan pada } \\
\text { kemasan }\end{array}$ & CON4 \\
\hline & & $\begin{array}{c}\text { Terdapat informasi } \\
\text { nilai gizi pada kemasan }\end{array}$ & CON5 \\
\hline & & $\begin{array}{c}\text { Kecocokan } \\
\text { pengaplikasian rasa } \\
\text { buah pada dodol }\end{array}$ & CON6 \\
\hline & & $\begin{array}{c}\text { Terdapat label dan } \\
\text { nomor lolos uji dari } \\
\text { Departemen kesehatan } \\
\text { pada kemasan }\end{array}$ & CON7 \\
\hline & & Kekenyalan dodol & CON 8 \\
\hline & & Kerenyahan dodol & CON 9 \\
\hline \multirow{2}{*}{4} & \multirow{2}{*}{ Durability } & Ketahanan kemasan & DUR 1 \\
\hline & & Ketahanan dodol & DUR 2 \\
\hline
\end{tabular}

